\title{
PERFORMANCE ANALYSIS OF RICE FARMING UTILIZING AGRICULTURAL EQUIPMENT AND MACHINERY RENTAL SERVICES IN MUARA TELANG DISTRICT OF BANYUASIN
}

\author{
Ariadi Zepri, Mulyana Andy, Yunita \\ Master's Program of Agribusiness, Faculty of Agriculture, University of Sriwijaya, Indonesia \\ *E-mail: zepriariadi@gmail.com
}

\begin{abstract}
Most farmers use agricultural equipment and machinery through services that are provided by rental services. This study was aimed to analyze and compare the performance of rice farming utilizing agricultural equipment and machinery services business (UPJA) and other rental services in Muara Telang district, Banyuasin Regency. This study used a survey method in which the respondents were determined using disproportionate stratified random sampling. The respondents consisted of 30 farmers who used UPJA services and 30 farmers who used other rental services. The results showed that the income earned by farmers who used UPJA services reached IDR9,275,713,-/ha, while farmers who used other rental services reached IDR8,579,429,-/ha. The estimation using the independent sample t-test showed that there was no significant difference between the productivity of those two groups. It also showed that there was no significant difference between the income of rice farming that used UPJA services and other rental services.
\end{abstract}

\section{KEY WORDS}

Agricultural equipment, machinery, services, farming, productivity, income.

Rice farming has an important meaning in agricultural development. This is inseparable from its role as a producer of the strategic commodities needed. Most of the population make this business as the main source of income. To achieve the expected conditions, rice farming requires some supporting components of production, one of which is through the use of agricultural machinery.

The development of rice farming through the implementation of the use of agricultural equipment and machinery can lead to time and cost efficiency, acceleration of IP, increased work and product quality, the enhancement of young workers interested in the agricultural sector, and the use of quality seeds with the amount of reduced seeds (Saliem et al., 2015). Likewise, for the government, the utilization has become one of the alternative solutions along with the occurrence of various problems that hamper agricultural development such as land conversion and labor shortages. Moreover, agricultural development is currently oriented towards increasing production.

Nevertheless, the adequacy of those tools in supporting increased production is still insufficient. In South Sumatra, one of the largest rice-producing provinces in Indonesia, the adequacy ratio of tractors, threshers, dryers, and combine harvesters only reached $17.5 \%$, $20.5 \%, 7 \%$, and $28 \%$ respectively (BPTP, 2018). Another problem concerns the less optimal use, the ability of farmers who are still limited, and the price that is not affordable for farmers.

Agricultural equipment and machinery ownership does not have a standard pattern. Generally, these can be owned by farmers, non-farmer individual entrepreneurs, agricultural tools service companies, farmer groups, and cooperatives. Farmers in utilizing agricultural tools and machinery use rental services or land management services more often without really having the required machinery (Tambunan and Sembiring, 2007). Umar (2014), explains the rental system of agricultural equipment and machinery for farming on tidal land is constrained by several things including agrotechnical constraints concerning the diversity of land conditions in the region, socio-economics regarding rental costs and other supports.

Agricultural Equipment and Machinery Service Business (UPJA) is one of the service businesses related to the use of agricultural machinery. UPJA is defined as a rural economic 
institution engaged in services in the context of optimizing the use of agricultural machinery for both inside and outside the farmer group to obtain business profits. Ariningsih and Tarigan (2005), explain that UPJA is social engineering that is intended to encourage the use of agricultural machinery by farmers. Economically, the existence of UPJA, if appropriately managed, will be able to increase the income and welfare of communities in rural areas.

According to Hanggana (2017), the main function of UPJA's institutions is to carry out economic activities in the form of agricultural equipment and machinery services of cultivation. The services offered include land preparation, irrigation, planting, plant protection, harvesting, and post-harvesting activities. Operationally, UPJA is directed to encourage the utilizitation of agricultural machinery by farmers or farmer groups, and at the same time is a breakthrough in overcoming the problem of individual ownership that is less profitable. Basically, the development of UPJA is intended to be able to build a system of agricultural machinery service business in a food crop production center that is business-oriented. In addition, UPJA is expected to be able to have an impact on employment and increase farmers' income (Directorate General of Food Crops, 2010).

Muara Telang is the largest rice-producing district in Banyuasin Regency, South Sumatra Province, Indonesia. In these areas, the use of agricultural equipment and machinery has been commonly used by farmers through either private ownership or rental services. The existence of UPJA as an economic institution through agricultural equipment and machinery services has grown and develop. It becomes of interest to farmers and is expected to help farmers to get a better income.

Based on the description above, this research focuses on the performance of rice farming utilizing agricultural equipment and machinery from UPJA services and other rental services through rice productivity and income indicators.

\section{LITERATURE REVIEW}

Kadalsan (1993) in Shinta (2011), defines farming as a place where a person or group of people try to manage the elements of production such as land, labor, capital, and skills to produce something on the agricultural field. Production refers to the transformation of various resources into outputs of goods or services (Salvatore, 2001).

Suhendratata (2015), conducted research on the application of mechanization on rice farming in Ngarum Village, Sragen, Central Java. The results showed that the use of rice transplanters could increase planting time efficiency ( 1 ha/day), labor (2-3 people/unit), and seed and planting costs of IDR2,100,000/ha. Besides that, productivity increased by $500-700$ $\mathrm{kg} / \mathrm{ha}$ compared to the manual method. Using a combine harvester can provide benefits derived from harvest losses of 450-650 kg/ha. Researched by Suyatno et al. (2018) showed that the use of the seed, fertilizer, and labor inputs were almost the same between the research sites in Tebas and the research in Semparuk Districts, Sambas, West Kalimantan. However, it has different productivity. The difference between rice productivity in Tebas District and rice productivity in Semparuk District is because of the use of a tractor for land processing in Semparuk District.

Research conducted by Sugiarto (2010) on the impact of UPJA on the performance of rice farming in Central Java and South Sulawesi conclude that the availability of agricultural machinery for farmers using UPJA had a positive impact in increasing economic benefits, marked by a higher $\mathrm{B} / \mathrm{C}$ ratio compared to farmers who do not use UPJA.

According to BPS (2015), the largest component of service costs in food crop farming is rental agricultural machinery. This situation reflects the uneven supply so that the owner of agricultural machinery still enjoys a rent of market imperfections. Research conducted by Oktovianto et al (2018) has shown that costs incurred at the tillage stage have no significant effect between farmers applying mechanization through UPJA and farmers who did not do so. Nevertheless, the farm earnings that use mechanization through UPJA is significantly higher than farmers from non-UPJA. 


\section{METHODS OF RESEARCH}

This study had been carried out in the villages of Telang Makmur and Sumber Mulya, Muara Telang District, Banyuasin Regency with the consideration that both villages have quite developed UPJAs (UPJA Barokah Telang Makmur and UPJA Amanah Jaya). This study used a survey method in which the respondents were determined using disproportionate stratified random sampling. The respondents consisted of 30 farmers who used UPJA services and 30 farmers who used other rental services.

Primary data in the form of rice farming data in the first planting season (October 2018 - March 2019) were obtained through interviews with the respondents. Primary data were also obtained through observation and interviews with UPJA managers and farmers. While supporting data were obtained through documents, reports, statistical data, or journals that have relevance to the study.

The calculation of revenue and income used the following equation (Soekartawi, 2002):

$$
\begin{aligned}
& \mathrm{TR}=\mathrm{Py} . \mathrm{Y} \\
& \Pi=\mathrm{TR}-\mathrm{TC}
\end{aligned}
$$

Where: $\pi=$ Income (IDR); TR = Total revenue (IDR); TC = Total cost (IDR); Py = Price of $Y$ (IDR / kg); $\mathrm{Y}=$ Total production ( $\mathrm{kg}$ ).

To analyze differences in rice farming performance through productivity between rice farming utilizing agricultural equipments and machinery through UPJA and other rental services, the following hypothesis was used:

$\mathrm{HO}$ : There is no significant difference between productivity for farmers who used UPJA services and who used other rental services;

$\mathrm{H} 1$ : There is a significant difference between productivity for farmers who used UPJA services and who used other rental services.

Independent sample t-test as in the following equation:

$$
\text { t stat }=\frac{\mathrm{x} 1-\mathrm{x} 2}{\sqrt{\frac{(\mathrm{n} 1-1) \mathrm{s} 12+(\mathrm{n} 2-1) \mathrm{s} 12}{\mathrm{n} 1+\mathrm{n} 2-2}\left(\frac{1}{\mathrm{n} 1}+\frac{1}{\mathrm{n} 2}\right)}}
$$

The basis of decision making was determined; if the significance value $<0.05$ then $\mathrm{H} 0$ was rejected, conversely if the significance value $\geq 0.05$ then $\mathrm{H} 0$ was accepted.

The equation and hypothesis above were also used to find out the difference in income between farmers who used UPJA services and who used other rental services.

\section{RESULTS AND DISCUSSION}

The application of agricultural machinery in rice farming in the Muara Telang was still partial. All respondents have used a tractor in the process of land management. The difference between those farmers lied in the type of tractor used. UPJA which serves farmers at this stage used four-wheel tractors while other rental services used two-wheel tractors (hand tractor). In the next tillage process, the two groups used a two-wheeled tractor (hand tractor).

In the harvest process, farmers who used UPJA service utilized a combine harvester and labor provided by UPJA. For this reason, they paid a service fee with the distribution of yield known as bawon 1:7, where the farmer got 7 parts of the harvest, and UPJA got only 1 part. Another group also used a combine harvester by sharing the same yield as UPJA. However, $13 \%$ of farmers in this group used thresher because the land was hard to pass through the combine harvester. These results in a smaller yield sharing in a ratio of 1:6, where farmers got 6 parts and the service provider got 1 part.

The utilization also influenced the needs of other production inputs. Based on the data obtained, it was known that the average area of land used by farmers who used UPJA 
services was 2.22 ha with labor requirements of $51.5 \mathrm{HOK} / \mathrm{ha}$, while farmers that used agricultural equipment and machinery through other rental services was 2.1 ha with a labor requirement of $57.8 \mathrm{HOK} / \mathrm{ha}$. UPJA providing land management services using a fourwheeled tractor with 1 operator only took 3-4 hours to work on an area of 1 ha while other service used 2 two-wheeled tractor operators to work on the same area of land within 8 hours. Besides, the use of threshers in a small proportion of respondent farmers who used agricultural equipment and machinery services other than UPJA required more labor compared to using a combine harvester.

Other production inputs in the form of seeds, fertilizers (Urea, SP 36, and Phonska), and pesticides in rice farming that used UPJA services were used in lower amounts than those through other rental services. Farmers who used UPJA services used an average of $71.75 \mathrm{~kg} / \mathrm{ha}$ of seeds, $205 \mathrm{~kg} / \mathrm{ha}$ of Urea, $110.7 \mathrm{~kg} / \mathrm{ha}$ of SP $36,112 \mathrm{~kg} / \mathrm{ha}$ of Phonska, and 7.7 liters $/$ ha of pesticides. Whereas other group used an average of $74.7 \mathrm{~kg} / \mathrm{ha}$ of seed, $208.3 \mathrm{~kg} / \mathrm{ha}$ of Urea, $117.8 \mathrm{~kg} / \mathrm{ha}$ of SP 36, $118 \mathrm{~kg} / \mathrm{ha}$ of Phonska, and 7.9 liters of pesticides.

Table 1 - Calculation of Productivity Difference between Rice Farming that Used UPJA Services and Rice Farming that Used Other Rental Services

\begin{tabular}{lllllll}
\hline & & & \multicolumn{3}{c}{ t-test for Equality of Means } \\
\cline { 3 - 7 } & & & \multirow{2}{*}{$\begin{array}{l}\text { Std. Error } \\
\text { Difference }\end{array}$} \\
\hline \multirow{2}{*}{ Productivity } & Equal variances assumed & & \multicolumn{2}{c}{$\begin{array}{l}\text { Sig. } \\
\text { (2-tailed) }\end{array}$} & $\begin{array}{l}\text { Mean } \\
\text { Difference }\end{array}$ \\
\cline { 2 - 7 } & Equal variances not assumed & 0.626 & 58 & 0.534 & 92.66667 & 148.12333 \\
\hline
\end{tabular}

Source: Primary Data (modified).

The rice productivity of farmers who used UPJA services was $6,013 \mathrm{~kg} / \mathrm{ha}$, and farmers who used other rental services was $5,921 \mathrm{~kg} / \mathrm{ha}$. Calculations using the t-test of rice productivity produced by the two groups can be seen in Table 1. These calculations were initially done to answer differences in productivity as an indicator of performance of rice farming. Based on Table 1, the Sig (2-tailed) value of 0.534 was obtained and the value was higher than 0.05 (>0.05). Thus, $\mathrm{H} 0$ was accepted and $\mathrm{H} 1$ was rejected. It means that there is no significant difference in rice productivity between those groups.

Table 2 - Costs and Income of Rice Farming that Used UPJA Services and Rice Farming that Used Other Rental Services

\begin{tabular}{|c|c|c|c|c|c|}
\hline & \multirow[t]{2}{*}{ Information } & \multicolumn{2}{|c|}{$\begin{array}{l}\text { Rice Farming that Used UPJA } \\
\text { Services }\end{array}$} & \multicolumn{2}{|c|}{$\begin{array}{l}\text { Rice Farming that Used } \\
\text { Other Rental Services }\end{array}$} \\
\hline & & Total (IDR) & $\%$ of TC & Total (IDR) & $\%$ of TC \\
\hline \multirow[t]{3}{*}{1.} & Revenue (R) & $24,490,949$ & & $23,938,603$ & \\
\hline & Productivity $(\mathrm{Kg} / \mathrm{Ha})$ & 6,013 & & 5,921 & \\
\hline & Price (IDR/Kg) & 4,073 & & 4,043 & \\
\hline \multirow[t]{8}{*}{2.} & Variable Cost (VC) & $4,637,590$ & 30.48 & $4,853,602$ & 31.60 \\
\hline & Seeds $(\mathrm{Kg} / \mathrm{Ha})$ & 589,570 & 3.87 & 600,588 & 3.91 \\
\hline & Fertilizer & $1,002,495$ & 6.59 & $1,046,397$ & 6.81 \\
\hline & - Urea $(\mathrm{Kg} / \mathrm{Ha})$ & 394,625 & & 403,061 & \\
\hline & - SP $36(\mathrm{Kg} / \mathrm{Ha})$ & 293,262 & & 313,290 & \\
\hline & - Phonska (Kg/Ha) & 314,608 & & 330,046 & \\
\hline & Pesticide (Ltr/Ha) & 791,478 & 5.20 & 820,427 & 5.34 \\
\hline & Labor $(\mathrm{HOK} / \mathrm{Ha})$ & $2,254,048$ & 14.81 & $2,386,190$ & 15.54 \\
\hline \multirow[t]{4}{*}{3.} & Fixed Cost (FC) & $10,577,646$ & 69.52 & $10,505,572$ & 68.40 \\
\hline & Land renting (IDR/Ha) & $6,033,000$ & 39.65 & $5,933,000$ & 38.63 \\
\hline & $\begin{array}{l}\text { Agricultural equipment and machinery service } \\
\text { costs (IDR/Ha) }\end{array}$ & $4,244,646$ & 27.90 & $4,222,572$ & 27.49 \\
\hline & Other & 300,000 & 1.97 & 350,000 & 2.28 \\
\hline 4. & Total Cost (TC) & $15,215,236$ & & $15,359,174$ & \\
\hline 5. & Income $(\mathrm{I}) / \mathrm{Ha}$ & $9,275,713$ & & $8,579,429$ & \\
\hline
\end{tabular}

Source: Primary Data (modified).

To analyze the difference in incomes, it is necessary to know in advance the receipts received and the costs incurred by the farm.

Based on Table 2, it was known that the revenue of rice farming that used UPJA services was greater than other rice farming with a difference of IDR552,346.- This was due 
to differences in productivity and the selling price of rice, where higher production and selling prices of rice was obtained by rice farming that utilizes UPJA services. Regarding the selling price of rice, based on information from UPJA managers, farming that used UPJA services, especially in the village of Telang Makmur, do planting earlier so that harvest time is faster than other regions. The advantage of this pattern is that the selling price is higher than in other regions that experience harvest time afterward.

Land (assumed to be rented), agricultural equipment and machinery services, and labor were the largest percentage of costs in the two groups. The percentages in rice farming that used UPJA services were valued at $39.65 \%, 27.90 \%$, and $14.81 \%$ respectively. While the three percentages of the cost for farming that used other rental services were $38.63 \%$, $27.49 \%$, and $15.54 \%$. The cost of using other production factors (seeds, fertilizers, and pesticides) has a percentage below $10 \%$ in both groups.

The costs incurred by farmers to obtain agricultural equipment and machine services were not much different. This also showed that the existence of UPJA especially in the first planting season (IP 100) is not followed by lower service costs compared to service businesses that had been dominated by farmers who had agricultural machinery/businessmen and farmer groups. The efforts to determine lower agricultural machinery service costs by UPJA would have an impact on other agricultural machinery service businesses that were firstly present at the research site. Furthermore, farmers would tend to wait for service businesses that offer lower costs, so that efforts to pursue the next planting period will be disrupted simultaneously. UPJA is also profit-oriented. For this reason, an equal rental price is set between UPJA and other rental services.

Table 3 - Calculation of Income Differences between Rice Farming that Used UPJA Services and Rice Farming that Used Other Rental Services

\begin{tabular}{clccccc}
\hline & & \multicolumn{4}{c}{ t-test for Equality of Means } \\
\cline { 3 - 7 } & \multirow{2}{*}{ Income } & \multirow{2}{*}{ Df } & Sig. (2-tailed) & $\begin{array}{c}\text { Mean } \\
\text { Difference }\end{array}$ & $\begin{array}{c}\text { Std. Error } \\
\text { Difference }\end{array}$ \\
\cline { 2 - 7 } & Equal variances assumed & 1.586 & 58 & 0.118 & 681435.1 & 429636.19 \\
\cline { 2 - 7 } & Equal variances not assumed & 1.586 & 57.79 & 0.118 & 681435.1 & 429636.19 \\
\hline
\end{tabular}

Source: Primary Data (modified).

Rice farming income that used UPJA services reached IDR9,275,713,-/ha and rice farming that used other rental services earned IDR8,579,429,-/ha. The estimation results made using the independent sample t-test as shown in table 2 showed a value higher than 0.05 . Based on this value, it was known that there was no significant difference between rice farming that used UPJA and the other rental services.

\section{CONCLUSION AND SUGGESTIONS}

From the analysis conducted in this study, it can be concluded that rice farming performance shown through indicators of income and production in rice farming utilizing agricultural equipments and machinery through UPJA and other rental services showed no significant differences. Based on these results, it is recommended to service providers to reduce service costs considering that these costs are one of the biggest costs that must be paid by farmers. It is also recommended to UPJA to increase the availability of agricultural equipment and machinery and to socialize the use of other agricultural machinery that can increase rice production such as rice transplanter.

\section{REFERENCES}

1. Aldillah, Rizma. 2016. Kinerja Pemanfaatan Mekanisasi Pertanian and Implikasinya dalam Upaya Percepatan Produksi Pangan di Indonesia. Forum Penelitian Agro Ekonomi, Vol. 34 No.2, Desember 2016. 
2. Aringsih, Ening and Herlina Tarigan. 2005. Keragaan Usaha Pelayanan Jasa Alsintan (UPJA) di Jawa Barat: Studi Kasus di Kabupaten Indramayu. ICASEPS Working Paper No. 79. Pusat Analisis Sosial Ekonomi and Kebijakan Pertanian.

3. Badan Penelitian and Pengembangan Pertanian. 2018. Pemetaan Alat and Sarana Pertanian Provinsi Sumatera Selatan. Kementerian Pertanian Republik Indonesia.

4. Badan Pusat Statistik. 2015. Policy Brief Peningkatan Kinerja Pertanian Indonesia Menuju Kedaulatan Pangan. Badan Pusat Statistik. Jakarta.

5. Badan Pusat Statistik. 2017. Kabupaten Banyuasin dalam Angka 2017. BPS Kabupaten Banyuasin.

6. Direktorat Jenderal Tanaman Pangan. 2010. Pedoman Pelaksanaan Usaha Jasa and Pelayanan Alat and Mesin Pertanian (UPJA) Tahun 2010. Kementerian Pertanian Republik Indonesia.

7. Handaka and Abi Prabowo. 2013. Kebijakan Antisipatif Pengembangan Mekanisasi Pertanian. Analisis Kebijakan Pertanian. Volume 11 No. 1, Juni 2014.

8. Hanggana, Sri. 2017. Analisis Kelemahan Regulasi Poktan, Gapoktan, UPJA, and LKMA dalam Peningkatan Pendapatan Petani. Analisis Kebijakan Pertanian, Vol. 15 No. 2, Desember 2017.

9. Laksmi, Ni Made Ayu Citra., I Ketut Suamba and I.G.A.A Ambarawati. 2017. Analisis Efisiensi Usahatani Padi Sawah (Studi Kasus di Subak Guama, Kecamatan Marga, Kabupaten Tabanan). EJournal Agribisnis and Agrowisata ISSN: 2301-6523 Vol. 1, No. 1, Juli 2012.

10. Marpaung, Imelda S., Tumarlan Thamrin and Yanter Hutapea. 2016. Peningkatan Produktivitas Padi Melalui Perbaikan Sistem Produksi di Lahan Pasang Surut Sumatera Selatan. Prosiding Seminar Nasional Lahan Suboptimal, 20-21 Oktober 2016. Palembang.

11. Oktovianto, Kurnia Arif., Irham, and Suhatmini Hardyastuti. 2018. The Impact of Mechanization under UPJA Program on Rice Farming Income in Prambanan Sub-District Sleman District. Agro Ekonomi, Vol 29/No.1.

12. Saliem, Handewi P., Ketut Kariyasa., Henny Mayrowani., Adang Agustian., Supena Friyatno., and Sunarsih. 2015. Prospek Pengembangan Pertanian Modern Melalui Penggunaan Teknologi Mekanisasi Pertanian Pada Lahan Padi Sawah. Pusat Sosial Ekonomi and Kebijakan Pertanian. Badan Penelitian and Pengembangan Pertanian.

13. Shinta, Agustina. 2011. Ilmu Usahatani. UB Press. Malang.

14. Soekartawi. 2002. Prinsip Dasar Ekonomi Pertanian, Teori and Aplikasinya. PT. Raja Graffindo Perkasa. Jakarta.

15. Sugiarto. 2010. Analisis Kinerja UPJA Menunjang Kegiatan Usahatani Padi. Jurnal Penelitian Pertanian Terapan, Vol. 10 No.2, Mei 2010.

16. Suhendrata, Tota. 2015. Pengembangan Penerapan Mekanisasi pada Usahatani Padi Sawah Melalui Pemberdayaan Kelembagaan Petani: Studi Kasus di Desa Ngarum, Kabupaten Sragen, Jawa Tengah. Prosiding Seminar Nasional Perlindungan and Pemberdayaan Pertanian Dalam Rangka Pencapaian Kemandirian Pangan Nasional and Kesejahteraan Petani. Badan Penelitian and Pengembangan Pertanian.

17. Umar, Sudirman. 2013. Pengelolaan and Pengembangan Alsintan untuk Mendukung Usahatani Padi di Lahan Pasang Surut. Jurnal Teknologi Pertanian, Vol.8 No.2.

18. Suyatno, Adi., Imelda., and. Komariyati. 2018. Pengaruh Penggunaan Traktor Terhadap Pendapatan and Penggunaan Tenaga Kerja pada Usahatani Padi di Kabupaten Sambas. AGRARIS: Journal of Agribusiness and Rural Development Research, Vol 4 No. 2.

19. Tambunan, Armansyah H., and. E. Namaken Sembiring. 2007. Kajian Kebijakan Alat and Mesin Pertanian. Jurnal Keteknikan Pertanian. Vol 21 No. 4, Desember 2007. 